\title{
An Online Support Group Intervention for Adolescents Living with HIV in Nigeria: A Pre-Post Test Study
}

Lisa Dulli ${ }^{1}$, MHS, PhD; Kathleen Ridgeway ${ }^{1}$, MSPH; Catherine Packer ${ }^{2}$, MSPH; Kate F Plourde ${ }^{3}$, MPH; Tolulope Mumuni $^{4}$, MSc; Tosin Idaboh ${ }^{5}$, MBBS, MPH, MSc, FMCPH; Adesola Olumide ${ }^{4}$, MBBS, MPH, FWACP, FMCPH; Oladosu Ojengbede ${ }^{4}$, MBBS, BSc., FMCOG, FWACS, FICS; Donna R McCarraher ${ }^{2}$, MPH, PhD

${ }^{1}$ Department of Program Sciences and Technical Support, Health Services Research, Family Health International (FHI 360), Durham, NC, United States

${ }^{2}$ Department of Reproductive, Maternal, Newborn and Child Health, Family Health International (FHI 360), Durham, NC, United States

${ }^{3}$ Department of Program Sciences and Technical Support, Research Utilization, Family Health International (FHI 360), Durham, NC, United States

${ }^{4}$ Center for Population and Reproductive Health (CPRH), College of Medicine, University of Ibadan, Ibadan, Nigeria

${ }^{5}$ Nigeria Country Office, Family Health International (FHI 360), Abuja, Nigeria

\section{Corresponding Author:}

Lisa Dulli, MHS, PhD

Department of Program Sciences and Technical Support, Health Services Research

Family Health International (FHI 360)

359 Blackwell Street

Durham, NC, 27701

United States

Phone: 19195447040

Email: 1dulli@fhi360.org

\section{Abstract}

Background: Adolescents living with HIV (ALHIVs) enrolled in HIV treatment services experience greater loss to follow-up and suboptimal adherence than other age groups. HIV-related stigma, disclosure-related issues, lack of social support, and limited HIV knowledge impede adherence to antiretroviral therapy (ART) and retention in HIV services. The 90-90-90 goals for ALHIVs will only be met through strategies targeted to meet their specific needs.

Objectives: We aimed to evaluate the feasibility of implementing a social media-based intervention to improve HIV knowledge, social support, ART adherence, and retention among ALHIV aged 15-19 years on ART in Nigeria.

Methods: We conducted a single-group pre-post test study from June 2017 to January 2018. We adapted an existing support group curriculum and delivered it through trained facilitators in 5 support groups by using Facebook groups. This pilot intervention included five 1-week sessions. We conducted structured interviews with participants before and after the intervention, extracted clinical data, and documented intervention implementation and participation. In-depth interviews were conducted with a subset of participants at study completion. Quantitative data from structured interviews and group participation data were summarized descriptively, and qualitative data were coded and summarized.

Results: A total of 41 ALHIV enrolled in the study. At baseline, $93 \%$ of participants reported existing phone access; $65 \%$ used the internet, and 64\% were Facebook users. In addition, 37 participants completed the 5-session intervention, 32 actively posted comments in at least one session online, and at least half commented in each of the 5 sessions. Facilitators delivered most sessions as intended and on-time. Participants were enthusiastic about the intervention. Aspects of the intervention liked most by participants included interacting with other ALHIVs; learning about HIV; and sharing questions, experiences, and fears. The key recommendations were to include larger support groups and encourage more group interaction. Specific recommendations on various intervention components were made to improve the intervention.

Conclusions: This novel intervention was feasible to implement in a predominantly suburban and rural Nigerian setting. Social media may be leveraged to provide much-needed information and social support on platforms accessible and familiar to many people, even in resource-constrained communities. Our findings have been incorporated into the intervention, and an outcome study is underway.

Trial Registration: ClinicalTrials.gov NCT03076996; https://clinicaltrials.gov/ct2/show/NCT03076996 (Archived by WebCite at http://www.webcitation.org/73oCCEBBC). 
(JMIR Public Health Surveill 2018;4(4):e12397) doi: 10.2196/12397

\section{KEYWORDS}

adolescents; digital health intervention; HIV care continuum; social support

\section{Introduction}

Despite important gaps in our understanding of the HIV epidemic among adolescents (age, 10-19 years), available data indicate that this age group experiences high rates of new HIV infection, has less access to treatment, and is more likely to discontinue treatment and die from HIV-related causes than other age groups [1,2]. More than $80 \%$ of adolescents living with HIV (ALHIVs) are in sub-Saharan Africa, where, despite considerable progress, treatment coverage remains challenging: By 2016, less than $50 \%$ of ALHIVs received treatment [1-3]. Between 2010 and 2016, HIV-related mortality among adolescents decreased by $5 \%$ globally and $14 \%$ in Eastern and Southern Africa; however, in Western and Central Africa, the related mortality increased by $15 \%$ [2].

In 2016, nearly $50 \%$ of HIV-related deaths among adolescents in Western and Central Africa occurred in Nigeria [2]. One contributing factor to the high mortality may be poor treatment retention among ALHIVs. A 2016 study of youth (age, 14-24 years) initiating antiretroviral therapy (ART) in Nigeria found that they were less likely to remain in treatment at 12 months (46\% vs $53 \%)$ and more likely to experience treatment disruptions ( $>3$ months between clinic visits) in their first year on ART than older adults (relative risk=1.15, $P=.008$ ) [4].

Fear of stigma or disclosure, lack of social support, and limited knowledge about the disease, compounded by the physical, social, and psychological changes of adolescence, create numerous challenges to successful treatment [5-10]. For example, adolescence is a time when relationships outside of the immediate family, such as those with peers, become very important [11]; however, because of HIV-related stigma and discrimination, ALHIVs rarely disclose their status to their peers for fear of losing them, which can negatively impact their psychosocial well-being and treatment [12-13].

Evidence of effective interventions to improve treatment outcomes among ALHIVs, particularly in low- and middle-income countries, is limited [14-15]. ALHIVs are also less likely than adults or younger children to be targeted with interventions to improve health outcomes [14,15]; however, some intervention strategies designed for adults may be effective for ALHIVs. Emerging evidence supports group counseling and structured support groups as effective ways to improve adherence and retention among adults [16-21]. Digital health interventions such as mobile phone reminders improved adherence among adults in some low- and middle-income countries [22-27]. Two recent studies targeting youth in South Africa and the United States demonstrated that online social network interventions could be acceptable and feasible in this population [28-29].

According to a 2014 survey, $89 \%$ of Nigerians aged $\geq 18$ years owned a mobile phone [30]. A 2012 study in Nigeria found that more than half of the females aged 12-30 years owned a phone, and almost all who did not own a mobile phone had access to one [31]. The rapid increase in mobile phone use in Nigeria indicates the potential of digital health strategies to help meet the support needs of ALHIVs.

In this study, we aimed to develop and test the feasibility and acceptability of a structured support group intervention-SMART (Social Media to promote Adherence and Retention in Treatment) Connections-which is delivered through a social media platform to improve retention in HIV health services and ART adherence among ALHIVs aged 15-19 years in periurban southern Nigeria.

\section{Methods}

\section{Design}

We conducted a mixed-methods, single-group, pre-post test study from June 2017 to January 2018. Participants were recruited from 3 health facilities in Akwa Ibom State and enrolled to receive 5 intervention sessions [32]. Data were collected through face-to-face interviews using a structured questionnaire at baseline and endpoint. In-depth interviews (IDIs) with a subset of purposively selected participants were conducted at endpoint and stratified by participation level. Participation data were collected using a Facebook group analytics tool [33]. The FHI 360 Protection of Human Subjects Committee, Durham, North Carolina, and the University of Uyo Teaching Hospital Ethics Committee Uyo, Akwa Ibom State, Nigeria, approved this study. Written informed consent was obtained from adult participants aged $\geq 18$ years. Written parental permission and adolescent assent were obtained from participants aged 15-17 years.

\section{SMART Connections: Development and Description}

SMART Connections was designed to promote ART adherence and retention in HIV services by leveraging informational, emotional, and network dimensions of social support. Content was adapted from sessions of the Positive Connections: Leading Information and Support Groups for Adolescents Living with HIV guide, to be delivered online through "secret" Facebook groups [34]. Secret Facebook groups limit membership and access to those invited and added by a group administrator. Content in secret Facebook groups can be seen only by members. These groups cannot be found through online search engines and do not appear on Facebook users' timelines; therefore, others who are not part of the group cannot determine whether a person is a member of a secret group [35].

Intervention components included informational messages and moderated group discussions, and 5 of 14 Positive Connections sessions were included in this study: Understanding HIV; Disclosure and Developing Trust in Relationships; Treatment and Adherence; Nutrition and Health; and Sex and Relationships. Sessions included activities for the facilitators 
to post and subsequently lead discussions. Within each session, the activities included the following: At a glance, to introduce the topic of the week (Figure 1); word of the week, to define one key concept for the topic (Figure 2); cartoons, to tell a story related to the topic (Figure 3); key messages, to deliver important information; quizzes, to assess participants' knowledge and stimulate discussion; and group discussions moderated by facilitators. Four facilitators, recruited from existing community-based organizations and previously trained to lead in-person support groups for people living with HIV, received a 1-week training on the intervention.

Study support groups began with an initial, in-person meeting during which participants met each other and the facilitator. The facilitator described the intervention and the group agreed upon ground rules for interactions, emphasizing the need to maintain confidentiality for group interactions. All participants received a basic mobile phone (also known as a feature phone) that could access Facebook, regardless of current phone ownership, because our primary interest was to determine whether the intervention could be implemented as designed and if participants would engage in it, given the opportunity. Participants selected the cellular network on which the phone was registered and were allowed to keep the phones at the end of the study. Each participant received 1000 Naira (USD 3.33) of data each month to facilitate participation, corresponding to 1.5-2 gigabytes of data monthly, depending on the network provider. This amount of data translates roughly to 300-400 social media posts with photos [36].

\section{Sample Size and Sampling Design}

We aimed to enroll 40-50 ALHIVs to form 5 support groups of 8-10 individuals. Eligibility criteria for ALHIVs for inclusion in the study were age, 15-19 years; on ART for >6 months; and basic literacy to participate in online chats. Literacy was assessed by data collectors during eligibility screening by asking the participant to read aloud three short sentences from the intervention content. If the data collector determined that the participant could read all or most of the sentences, the person was deemed eligible. Participants who could not read at all or struggled with all three sentences were deemed ineligible. ALHIVs who planned to move from the area before the end of the study, were enrolled in an in-person support group, were enrolled in another HIV-related research study, or were critically or severely ill at enrollment were excluded from the study.
Eligible participants were sequentially recruited during clinic visits. Additionally, participants were identified from medical records by a clinic staff and contacted by telephone to tell them about the study and, if interested, to come to the facility to learn more about the study. IDIs were conducted for 8 participants with moderate to high active participation and 8 participants with no to low active participation at the study endpoint.

\section{Measures}

We collected demographic information of participants (sex, age, relationship status, education, occupation, and religion) and their HIV infection (date of diagnosis, date of start of ART, disclosure to others, viral load, and CD4 [cluster of differentiation 4] results). We also collected data on preintervention access to mobile phones, the internet, and experience with social media.

We measured intervention implementation and participation using Grytics software [33]. To measure fidelity, we determined if intervention activities occurred within 1 week of when they were scheduled and the proportion of scheduled activities completed. In addition, we measured if and how participants participated in each scheduled activity. Group members could participate in several ways: commenting on a scheduled post, "liking" or "reacting" to a post or comment, making a new post, or commenting on or reacting to others' posts. IDIs explored participants' experiences with the intervention.

\section{Data Analysis}

Quantitative data were analyzed descriptively and independently verified by a second analyst. For participation data, posts (original message) and comments (replies to a post) were equally weighted and each assigned a value of 1 . Participation was categorized into approximate quartiles of total posts over the 5 sessions: none to very low (0-5 total posts), low (6-20 posts), moderate (21-50 posts), and high ( $\geq 51$ posts).

IDIs were audio recorded and transcribed into English. Some IDIs were conducted in local languages and then simultaneously transcribed and translated. Qualitative data were analyzed by an applied thematic approach using NVivo 11 [37,38]. A codebook was created on the basis of the interview guide, and emergent thematic codes were added during analysis. Two analysts coded the transcripts and checked $12 \%$ of the transcripts for intercoder reliability. Summary memos documented overall themes related to the study objectives. 
Figure 1. At a glance. *ART: antiretroviral therapy.

\section{At a glance \\ - HIV weakens the immune system and makes it harder for your body to protect you from getting sick. \\ - There is no cure for HIV or AIDS. \\ - People with HIV can live healthy lives if they take medicines for HIV called ART*. \\ - Follow your doctor's instructions for taking ART*. \\ - Taking ART* as your doctor tells you can make you feel better and lower the chances of you infecting others.}

Figure 2. Word of the week.

\section{Disclosure: telling someone you have HIV}

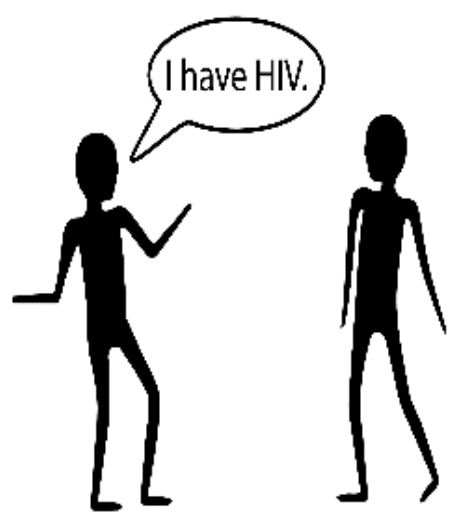


Figure 3. Sample cartoon. *ART: antiretroviral therapy.

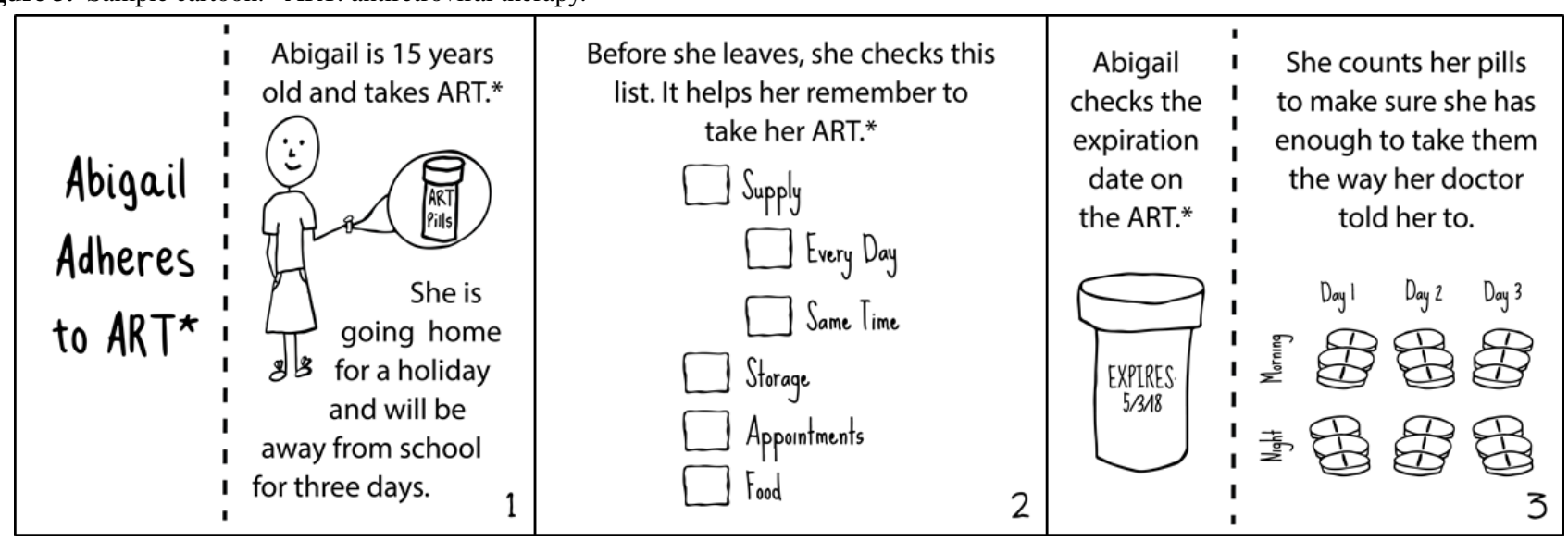

\section{Results}

A total of 41 adolescents enrolled in the study and completed a baseline interview, of whom 38 started the intervention and 35 completed the endpoint questionnaire. A flow chart describing the identification, enrollment, and follow-up of participants is presented in Figure 4.

Several individuals initially deemed eligible according to clinical records were later found to be ineligible due to incorrect age information in their medical records. Of those confirmed to meet eligibility criteria, 13 parents or guardians refused to allow their child to participate, 5 of whom stated they had not yet disclosed their child's HIV status to him or her.

Participants were nearly equally divided by sex (Table 1). About half of the participants were enrolled in school, mostly in secondary school, and one-quarter were employed. All participants had a home or primary residence. Most participants had been on ART for $>4$ years; $90 \%$ (37 of 41 ) had at least one CD4 cell count test recorded in their medical record, but only $73 \%$ (30 of 41) had a viral load test recorded in their medical record (Table 1). Among those with a recorded viral load, half were virally suppressed (Table 1). All participants who were not virally suppressed had viral loads $>5000$ copies $/ \mathrm{mL}$ (data not shown).

Figure 4. Study flow chart. *ALHIV: adolescent living with HIV. **In 5 cases, the guardians refused to let the child participate because they had not yet disclosed their child's HIV status to him or her. ***One participant did not complete the endpoint structured interview, but completed the in-depth interview.

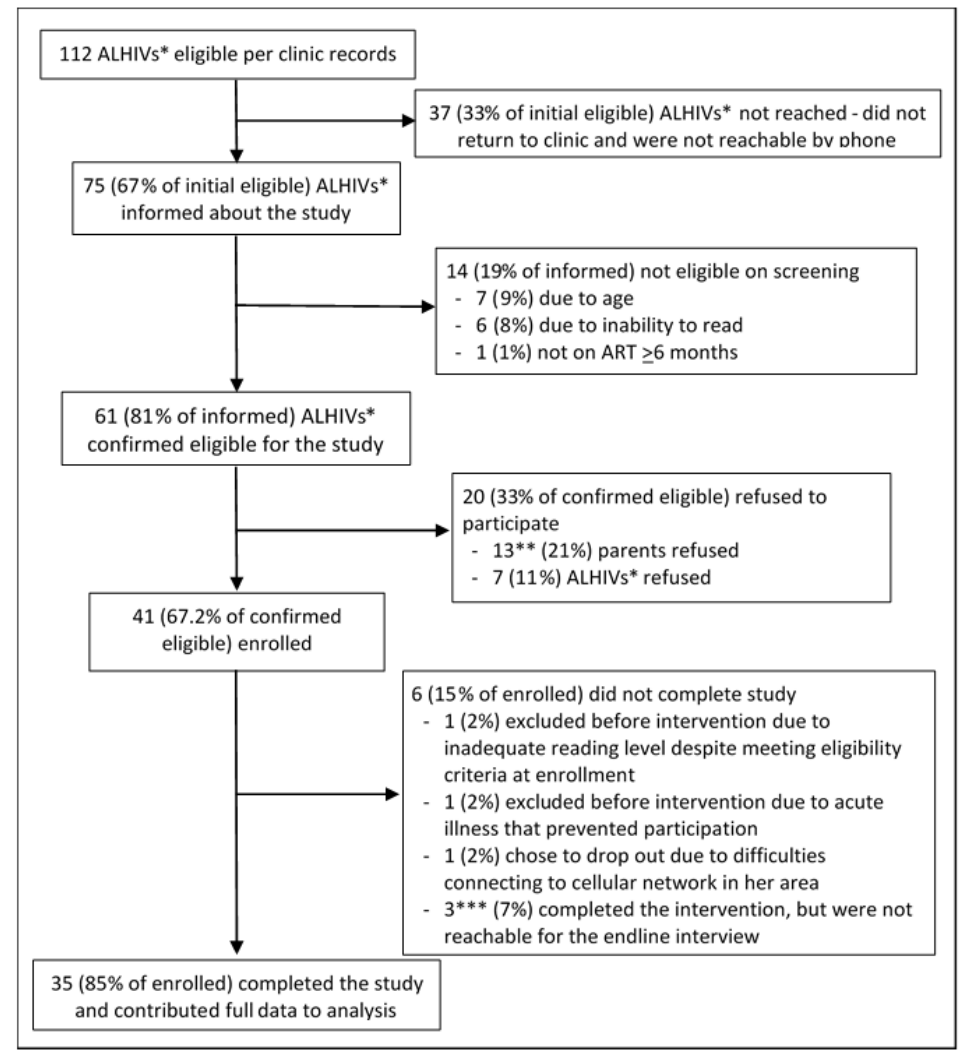


Table 1. Participant characteristics at baseline.

\begin{tabular}{|c|c|}
\hline Characteristic $(\mathrm{N}=41)$ & Value \\
\hline \multicolumn{2}{|l|}{ Sex, $\mathbf{n}(\%)$} \\
\hline Female & $22(53)$ \\
\hline Male & $19(46)$ \\
\hline Age (years), median (range) & $17(15-19)$ \\
\hline Currently employed, n (\%) & $11(26)$ \\
\hline \multicolumn{2}{|l|}{ Education, $\mathbf{n}(\%)$} \\
\hline Currently enrolled in secondary school & $18(43)$ \\
\hline Currently enrolled in postsecondary school & $2(4)$ \\
\hline Not currently enrolled, completed secondary school & $15(36)$ \\
\hline Not currently enrolled, completed some secondary school & $6(14)$ \\
\hline \multicolumn{2}{|c|}{ Among those in school, location of residence during school $(n=20), n(\%)$} \\
\hline Live at home & $19(95)$ \\
\hline Boarding school & $0(0)$ \\
\hline With a friend's family & $1(5)$ \\
\hline Has a primary household, $\mathrm{n}(\%)$ & $41(100)$ \\
\hline \multicolumn{2}{|l|}{ Religion, $\mathbf{n}(\%)$} \\
\hline Christian denomination & $41(100)$ \\
\hline Time on antiretroviral therapy ${ }^{\mathrm{a}}$ (years), median (range) & $4.0(0.5-11.0)$ \\
\hline $\mathrm{CD} 4^{\mathrm{b}}$ cell count at last test $(\text { cells } / \mu \mathrm{l})^{\mathrm{c}}$, median (range) & $414(16-957)$ \\
\hline \multicolumn{2}{|l|}{ Viral load at last test ${ }^{\mathbf{d}}, \mathbf{n}(\%)$} \\
\hline Suppressed viral load ( $<1000$ copies $/ \mathrm{mL})$ & $15(50)$ \\
\hline Unsuppressed ( $\geq 1000$ copies $/ \mathrm{mL})$ & $15(50)$ \\
\hline Viral load (copies/mL), median (range) & $31,210(5338-936,973)$ \\
\hline
\end{tabular}

${ }^{\mathrm{a}}$ Data for 6 participants missing.

${ }^{\mathrm{b}} \mathrm{CD} 4$ : cluster of differentiation 4 .

${ }^{\mathrm{c}}$ Data for 4 participants missing.

${ }^{\mathrm{d}}$ Data for 11 participants missing.

Three-quarters of all participants lived with one or both parents, and the rest lived with other family members, including one participant who was married and lived with the spouse (Table 2 ). The majority $(68 \%)$ reported that at least one parent knew of their HIV status; fewer participants had other family members who knew their status, and only $3(7 \%)$ reported that a close friend knew their status. Six participants stated they were in romantic relationships, and all but one participant reported that their partner knew their HIV status; 5 of the 6 participants knew their partner's HIV status.

\section{Feasibility}

At baseline, nearly all participants (93\%) had existing access to a phone, and most $(66 \%)$ ever used the internet (Table 3 ). Nearly all participants $(96 \%)$ who used the internet had used Facebook. Among those who had phone access before this study, most reported difficulty charging phones $(79 \%)$ or running out of airtime or phone credit (97\%) sometimes or often.
Nearly all participants (92\%) who completed the endpoint structured interview reported that connecting to Facebook was somewhat or very easy, and $97 \%$ stated that they wrote comments or asked questions during sessions (Table 4).

\section{Participant Engagement}

Most participants who completed the endpoint questionnaire (34 of 35) participated in the intervention sessions (Table 5). The majority of intervention participants took part in all sessions and reported actively commenting or asking questions at some point.

Participation varied widely by session and group (Figure 5). Within groups, participation varied considerably (Figure 6). Each group had 1-3 members who were considerably more active than the others. Two participants made $>100$ posts $(327$ and 155 posts; Figure 6). 
Table 2. Relationships and disclosure status at baseline.

\begin{tabular}{|c|c|}
\hline Characteristic $(\mathrm{N}=41)$ & $\mathrm{n}(\%)$ \\
\hline \multicolumn{2}{|l|}{ Lives with } \\
\hline Both parents & $14(34)$ \\
\hline Mother only & $12(29)$ \\
\hline Father only & $5(12)$ \\
\hline Spouse or partner & $1(2)$ \\
\hline Other relative (sister, grandparents, cousin, aunt, or uncle) & $9(21)$ \\
\hline \multicolumn{2}{|l|}{ Others who know the participant's HIV status ${ }^{\mathrm{a}}$} \\
\hline Parent(s) & $28(68)$ \\
\hline Sibling(s) & $12(29)$ \\
\hline Other family member(s) & $14(34)$ \\
\hline Close friend(s) & $3(7)$ \\
\hline Religious leader & $3(7)$ \\
\hline No one & $3(7)$ \\
\hline \multicolumn{2}{|l|}{ Relationship status $^{b}$} \\
\hline Married & $1(2)$ \\
\hline Unmarried, in a relationship & $5(12)$ \\
\hline Single & $34(85)$ \\
\hline Spouse, girlfriend, or boyfriend knows the participant's HIV status $(n=6)^{\mathrm{c}}$ & $5(83)$ \\
\hline \multicolumn{2}{|l|}{ Spouse, girlfriend, or boyfriend has HIV ( $n=6$ ) } \\
\hline Yes & $2(33)$ \\
\hline No & $3(50)$ \\
\hline Don’t know & $1(16)$ \\
\hline
\end{tabular}

${ }^{\mathrm{a}}$ More than one response possible.

${ }^{\mathrm{b}}$ Data for one participant missing.

${ }^{\mathrm{c}}$ One person reported that no one knew her status besides the health providers, but then reported that her partner knew her status. 
Table 3. Mobile phone and internet use from the baseline questionnaire.

\begin{tabular}{|c|c|}
\hline Characteristic $(\mathrm{N}=41)$ & $\mathrm{n}(\%)$ \\
\hline \multicolumn{2}{|l|}{ Mobile phone access } \\
\hline None & $3(7)$ \\
\hline Has own basic phone & $16(39)$ \\
\hline Has own smart phone & $3(7)$ \\
\hline No personal phone but has access to phone in household & $19(46)$ \\
\hline \multicolumn{2}{|l|}{ Among those who own or have access to phone $(n=38)$} \\
\hline \multicolumn{2}{|l|}{ Ways of typically using the phone ${ }^{a}$} \\
\hline Make voice calls & $38(100)$ \\
\hline Send texts or SMS ${ }^{\mathrm{b}}$ & $34(91)$ \\
\hline Send group texts or MMS & $12(31)$ \\
\hline Access internet & $21(55)$ \\
\hline Access social media & $22(57)$ \\
\hline \multicolumn{2}{|l|}{ Frequency of running out of airtime or credit } \\
\hline Rarely & $1(2)$ \\
\hline Sometimes & $27(71)$ \\
\hline Often & $10(26)$ \\
\hline \multicolumn{2}{|l|}{ Frequency of facing difficulty charging phone } \\
\hline Never or Rarely & $8(21)$ \\
\hline Sometimes & $25(65)$ \\
\hline Often & $5(13)$ \\
\hline Ever used the internet & $27(65)$ \\
\hline \multicolumn{2}{|l|}{ Among those who ever used the internet $(n=27)$} \\
\hline \multicolumn{2}{|l|}{ Source of internet access ${ }^{a}$} \\
\hline Own computer or laptop & $0(0)$ \\
\hline Computer or laptop in household & $2(7)$ \\
\hline Computer or laptop at friend's house & $5(18)$ \\
\hline Cyber cafe & $2(7)$ \\
\hline Own phone or tablet & $9(33)$ \\
\hline Phone or tablet in household & $21(77)$ \\
\hline Friend's phone & $1(3)$ \\
\hline \multicolumn{2}{|l|}{ Ever used social media sites ${ }^{a}$} \\
\hline Facebook & $26(96)$ \\
\hline WhatsApp & $12(44)$ \\
\hline Instagram & $3(11)$ \\
\hline Other (Twitter, Palmchat, IMO) & $7(25)$ \\
\hline
\end{tabular}

${ }^{\mathrm{a}}$ More than one response possible.

${ }^{\mathrm{b}}$ Data for one participant missing. 
Table 4. Intervention access reported in the endpoint questionnaire.

\begin{tabular}{ll}
\hline Parameter (N=35) & $\mathrm{n}(\%)$ \\
\hline Used the study phone to connect to Facebook & $34(97)$ \\
Status of the study phone at endpoint & $33(94)$ \\
$\quad$ In participant's possession & $2(5)$ \\
$\quad$ Stolen & $34(97)$ \\
Participated in the intervention at least once & $2(5)$ \\
Among those who participated at least once (n=34), level of ease connecting to Facebook with the phone \\
$\quad$ Very difficult & $11(32)$ \\
Somewhat easy & $21(61)$ \\
Very easy &
\end{tabular}

Table 5. Intervention engagement in the endpoint questionnaire.

\begin{tabular}{ll}
\hline${\text { Parameter }(\mathrm{N}=34)^{\mathrm{a}}}$ & $\mathrm{n}(\%)$ \\
\hline Logged in at least once for a session & $29(85)$ \\
Session 1-Understanding & $20(65)$ \\
Session 2-Disclosure and trust ${ }^{\mathrm{b}}$ & $25(76)$ \\
Session 3-Treatment and adherence & $29(85)$ \\
Session 4-Nutrition and health & $30(88)$ \\
Session 5-Sex and relationships & \\
Ways engaged & $33(100)$ \\
Read what the facilitator posted & $34(100)$ \\
Read comments posted by others & $26(87)$ \\
"Liked" comments by others ${ }^{\mathrm{d}}$ & $33(97)$ \\
Wrote comments or asked questions & \\
Engagement level during scheduled intervention (by number of posts or comments, $\mathbf{n}=\mathbf{3 8})^{\mathbf{e}}$ \\
Very low (0-5) & $11(29)$ \\
Low (6-20) & $11(29)$ \\
High (21-50) & $9(24)$ \\
Very high (51-327) & $7(18)$ \\
\hline
\end{tabular}

${ }^{\mathrm{a}}$ One participant did not participate in the online group in the endpoint questionnaire and was not asked the questions in this table.

${ }^{\mathrm{b}}$ Data for 3 participants missing.

${ }^{\mathrm{c}}$ Data for 1 participants missing.

${ }^{\mathrm{d}}$ Data for 4 participants missing.

${ }^{\mathrm{e}}$ All participants who started the intervention.

One group (Group 5) was the most active group overall, and the group's facilitator was the most active among all facilitators (Figure 7). Similarly, the group with the lowest member participation had a facilitator with the lowest activity.

\section{Challenges to Participation}

Through the IDIs, we explored the challenges faced during implementation that might affect participation. Just over half of the 16 IDI respondents mentioned occasional problems with charging their phone or running out of data. About one-third of
IDI respondents mentioned issues with cellular networks, including poor connectivity or slow data speed, of whom 2 participants lacked network coverage when they traveled and 3 had persistent network problems at home. One of them commented the following:

Whenever I don't have data I can't use the internet...when you are chatting online, like you are chatting somehow it can cut off. [low engager, 15-year-old male] 
Figure 5. Group posts per session.

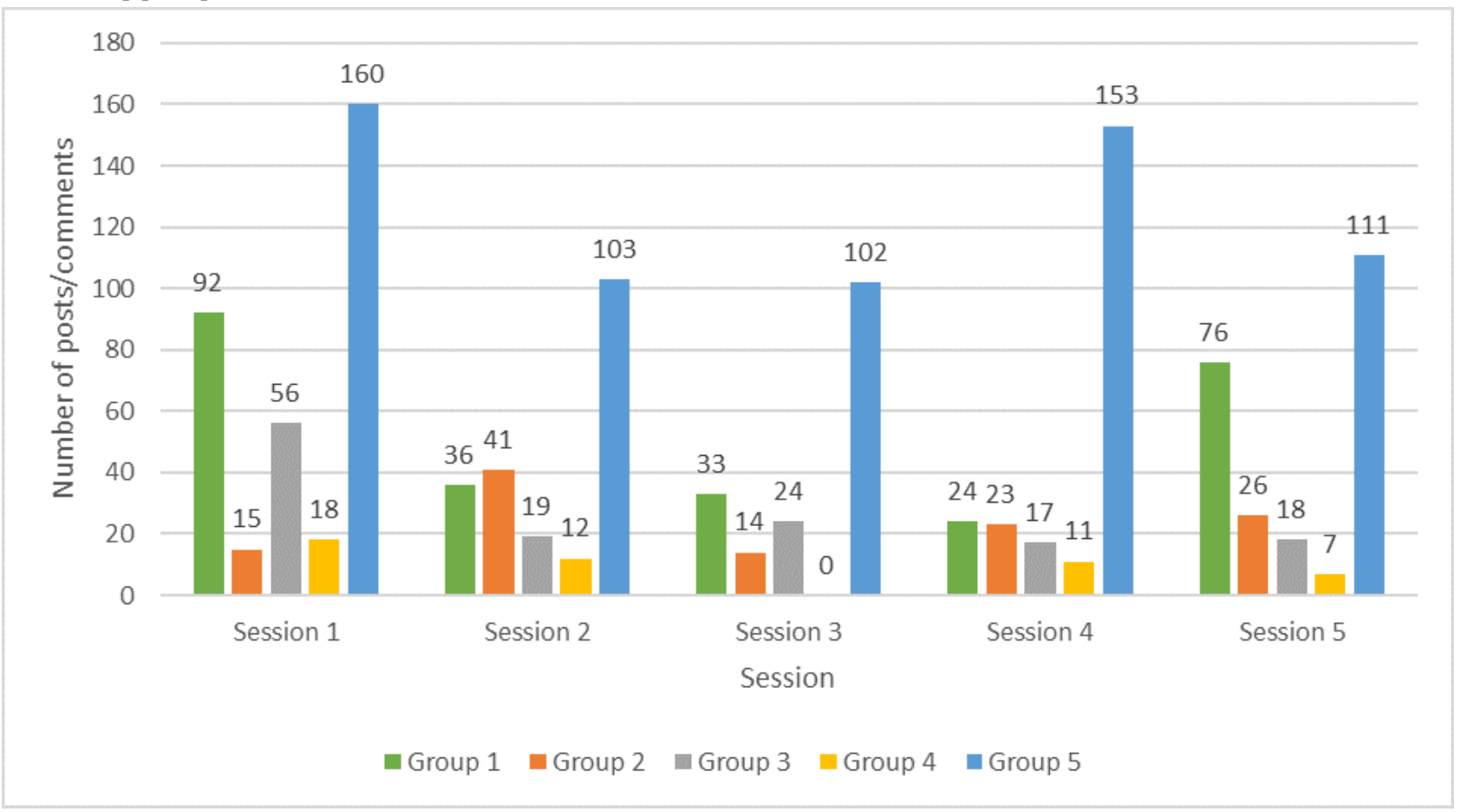

Figure 6. Individual posts per group.

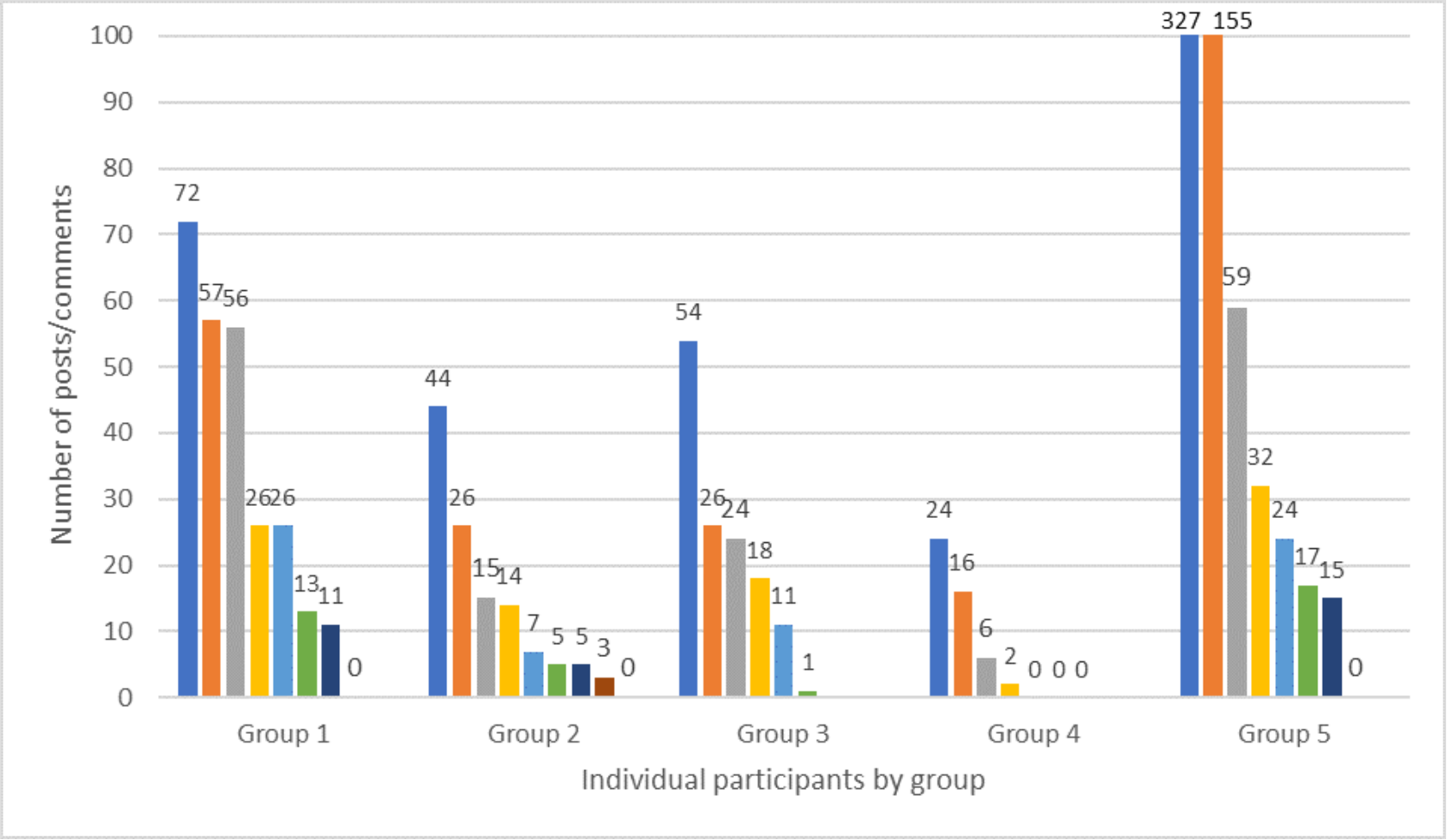


Figure 7. Number of posts or comments by group facilitators per session.

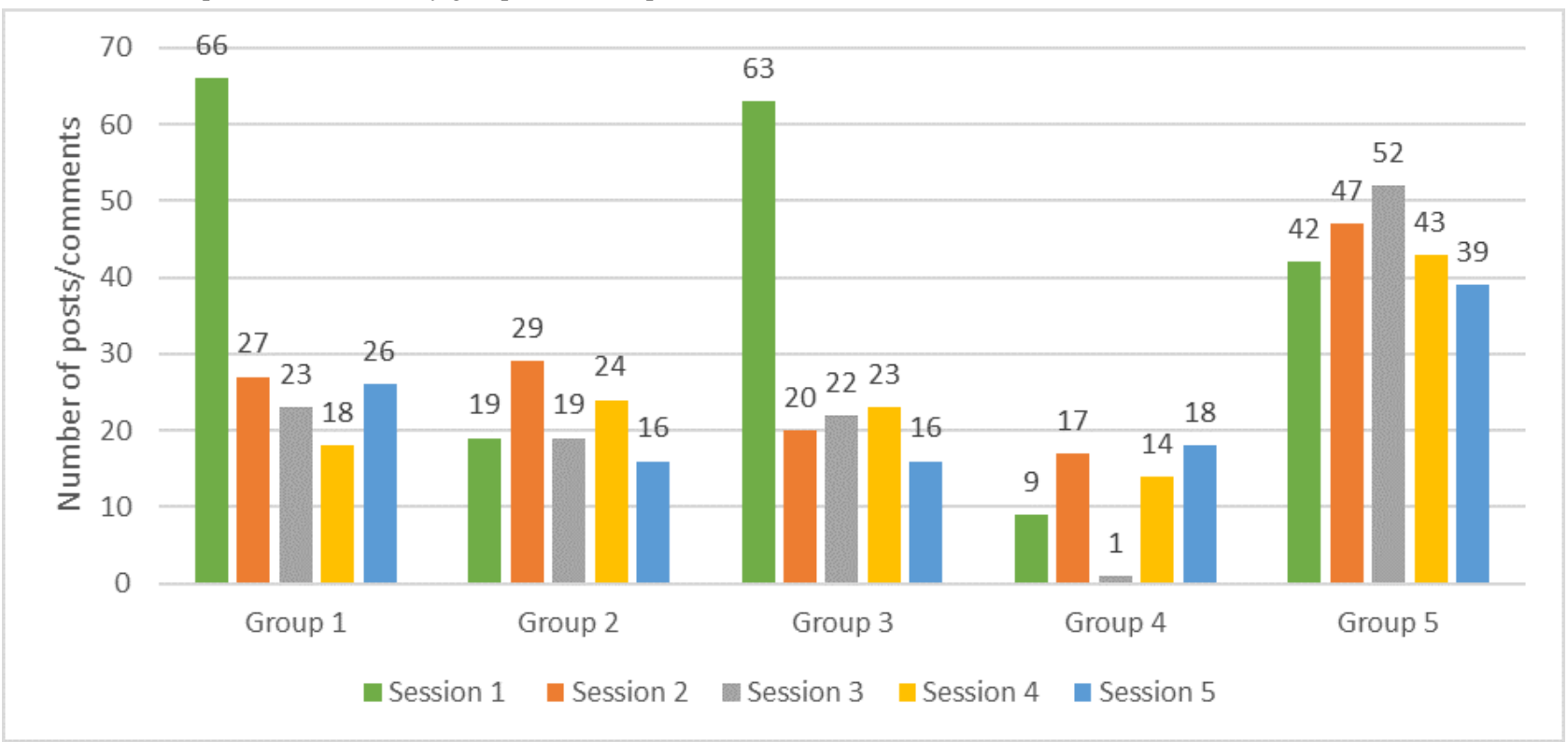

During the session on adherence, participants were asked to upload a photo of an adherence plan; however, none of the participants did so. Several IDI respondents described difficulties with photo uploads as the reason for not uploading an adherence plan photo. One other IDI respondent noted that the pictures did not always display correctly on his phone.

One IDI respondent said he thought another group member was sharing information publicly from the Facebook group, although he did not state that his HIV status or that of others was compromised:

Some of our members...will just pick what supposed to be post in [group name] to public Facebook and everybody will see it. I used to see some of them, some people who are in the public group start asking questions, are you, where, who are, where are from...So sometimes I used to sit them down in the Facebook and warn them. [high engager, 18-year-old male]

\section{Fidelity to Design}

Overall, each of the facilitators for the 5 groups posted most of the scheduled activities and did so on time (Table 6). Quizzes (polls) aimed to assess knowledge and stimulate discussion proved problematic. IDI respondents noted that quizzes did not appear correctly formatted on their phones. In response, facilitators posted quiz questions and response options as comments. 
Table 6. Proportion of activities posted and posted on time per session.

\begin{tabular}{|c|c|c|c|c|c|c|}
\hline Parameter & $\begin{array}{l}\text { Session } 1 \text { (6 activi- } \\
\text { ties), \% }\end{array}$ & $\begin{array}{l}\text { Session } 2 \text { ( } 7 \text { activi- } \\
\text { ties), \% }\end{array}$ & $\begin{array}{l}\text { Session } 3 \text { ( } 7 \text { activi- } \\
\text { ties), \% }\end{array}$ & $\begin{array}{l}\text { Session } 4 \text { ( } 7 \text { activi- } \\
\text { ties), } \%\end{array}$ & $\begin{array}{l}\text { Session } 5 \text { ( } 7 \text { activi- } \\
\text { ties), \% }\end{array}$ & All sessions, $\%$ \\
\hline \multicolumn{7}{|c|}{ Proportion of all activities posted (regardless of timing) } \\
\hline Group 1 & 100 & 100 & 100 & 71 & 100 & 94 \\
\hline Group 2 & 100 & 100 & 86 & 100 & 100 & 97 \\
\hline Group 3 & 100 & 100 & 100 & 100 & 86 & 97 \\
\hline Group 4 & 83 & 86 & 14 & 43 & 71 & 60 \\
\hline Group 5 & 100 & 100 & 100 & 100 & 85 & 97 \\
\hline All groups & 97 & 97 & 80 & 83 & 88 & \\
\hline \multicolumn{7}{|c|}{ Proportion of scheduled activities posted on time (within 1 week of schedule) } \\
\hline Group 1 & 100 & 100 & 100 & 71 & 100 & 94 \\
\hline Group 2 & 100 & 100 & 86 & 100 & 100 & 97 \\
\hline Group 3 & 100 & 100 & 100 & 100 & 86 & 97 \\
\hline Group 4 & 83 & 57 & 0 & 43 & 71 & 51 \\
\hline Group 5 & 100 & 100 & 100 & 43 & 0 & 69 \\
\hline All groups & 97 & 91 & 77 & 71 & 71 & $\mathrm{~N} / \mathrm{A}^{\mathrm{a}}$ \\
\hline
\end{tabular}

${ }^{\mathrm{a}} \mathrm{N} / \mathrm{A}$ : not applicable.

\section{Intervention Acceptability}

All participants who completed the endpoint questionnaire agreed that the intervention was useful: They enjoyed taking part in the Facebook group, felt comfortable with the facilitator and other group members, and wanted to continue to participate in the group (Table 7). In addition, participants unanimously felt that the Facebook group intervention was a good way for ALHIVs to interact and would recommend the group to other ALHIVs.

When asked to describe what they liked about the intervention, IDI respondents, both low and high engagers, most commonly reported that they enjoyed the intervention because it was educational or informative. They enjoyed "chatting," sharing experiences, and communicating with other ALHIVs; it helped them take care of themselves and their health (eg, most commonly, taking drugs on time) and felt supported or encouraged:

I am a very timid and shy person. But the intervention helped me. There are certain things I was able to overcome. I felt so miserable when I found out that I'm positive but after interacting with people, I find out that I don't have to kill myself or die or feel miserable...I have decided to open up and feel good about myself. [low engager, 18-year-old female]

It has affected my life in a way that, I don't have anything like stigmatization in me I don't and I don't feel someone can discriminate me then I will start looking down on myself. I feel comfortable, I feel I have confidence in myself. Like disclosure, I'm not afraid, am not shame, I'm not shy to expose everything to my partner when is time to get married.
So, I really like it has really done a lot of things in my life. [high engager, 18-year-old male]

A few participants mentioned that they liked the confidentiality of the online forum and learning how to use Facebook:

I feel safe from exposing my status to other people. It was very good, I like it...Well, what I feel about having a Facebook group is very, very secured. [high engager, 18-year-old male]

One participant was concerned about people learning of her HIV status by looking at the phone, but now feels comfortable:
At first, I was very scared. I was like what if someone should just carry my phone and see and say ha! what is this? But I was scared,...later on I became used to it, I wasn't afraid if someone should pick up my phone and see it. [high engager, 18-year-old female]

A few participants said they did not like low participation from other group members:

There's something I didn't like because we were 8 in number in that group and anytime or sometimes when I go online, I will only see only one chat or sometimes I won't see anybody. [high engager, 16-year-old male]

\section{Future Directions}

Participants had few specific recommendations to change the intervention. Recommendations from the endpoint questionnaires (Table $7, \mathrm{n}=34$ ) included the following: encourage group members to be more active (23\%); increase the size of the group (14\%); provide better instructions for Facebook (8\%); and use of other social media, specifically WhatsApp (5\%). Two participants thought some group members may require more explanation on using Facebook in terms of etiquette for posting comments. When asked whether both sexes 
should be included in future groups, 94\% of endpoint questionnaire respondents said yes (Table 7). Just over half the participants (55\%) favored inclusion of older youths, but several wanted to cap the age at 19 years. Participants who wanted to include older youths said younger participants could learn from older participants; those who preferred the current age range said younger ALHIVs may be afraid or less open to interacting with older youths. When asked whether they would prefer to be part of an online support group, in-person support group, or both, $58 \%$ of participants preferred an online group only and $41 \%$ preferred both groups. None of the participants preferred an in-person support group without the online group.

Table 7. Participants' perspectives on the intervention in the endpoint questionnaire.

\begin{tabular}{ll}
\hline Characteristic $(\mathrm{N}=34)^{\mathrm{a}}$ & $\mathrm{n}(\%)$ \\
\hline Agree with the following & $34(100)$ \\
Enjoyed being a member of the online support group & $34(100)$ \\
Received useful information & $34(100)$ \\
Participating in the group improved understanding of HIV & $34(100)$ \\
Felt comfortable interacting with other HIV-positive young people in the group & $34(100)$ \\
Felt comfortable interacting with the group facilitator & $30(88)$ \\
Made new friends in the group & $34(100)$ \\
Would like to continue to be part of the group & $34(100)$ \\
Thinks Facebook groups are a good way for ALHIV ${ }^{\mathrm{b}}$ to interact & $34(100)$ \\
Thinks Facebook groups are a good way for support group leaders to get information to ALHIVs & $34(100)$ \\
Would recommend this group to other young people living with HIV
\end{tabular}

\section{Ways to improve the intervention}

Encourage participation

Increase group size

Improve participant knowledge on Facebook use

Include WhatsApp texting

Specify a time to $\log$ in and be active

More encouragement for participants to ask questions

Encourage phone calls between participants

Have a monthly group meeting

Introduce the intervention elsewhere so others can benefit

\section{Recommendations for future group structure}

Groups should remain mixed sex

Groups should include older youths (aged up to 21 or 22 years)

Would prefer support group that met

$\begin{array}{ll}\text { Online only } & 20(58) \\ \text { In-person only } & 0(0) \\ \text { Combined online and in-person } & 14(41)\end{array}$

\footnotetext{
${ }^{\mathrm{a}}$ In the endpoint questionnaire, one participant said they did not participate in the online group and was not asked the questions in this table.

${ }^{\mathrm{b}}$ ALHIV: adolescents living with HIV
}

\section{Discussion}

This online support-group intervention was feasible to implement and highly acceptable among the ALHIVs who participated in the study. We obtained important information on specific challenges and ways to improve the intervention in order to enhance delivery and participation.
The level of active participation varied, within and across groups, which is similar to in-person support groups [21]. Group participation appeared to correlate with facilitator activity, although other factors such as logistic issues also played a role in individual participation within groups. Notably, the facilitator with the lowest overall participation performed the worst on timely and complete posting of sessions. In the future, experienced, dynamic facilitators with adequate mastery of 
intervention delivery should be recruited; however, even participants with low active participation reported high levels of satisfaction and appear to have benefitted from the intervention. With social media, the ability to follow conversations may allow those who are not comfortable commenting, to learn from others in the group [39,40]. Basic literacy was an important factor to the success of the intervention. Education levels are relatively high in southern Nigeria; $75.9 \%$ of women aged $15-49$ years have completed some secondary school or higher education [41]. As such, implementing this intervention for individuals with low education levels could prove more difficult.

The time taken for identification and enrolment of adolescents through health facilities was longer than anticipated. Although Nigeria bears the second-highest burden of HIV on the continent in terms of absolute numbers of people infected [42], its prevalence is relatively low, with higher pockets of concentration in certain geographic areas [43]. According to the recently conducted AIDS Indicator Survey in Akwa Ibom State (2017), HIV prevalence among adolescents aged 15-19 years is $1.5 \%$ [44]. Facility staff attempted, without success, to reach several patients through their recorded contact information, which highlights the challenge of poor retention in health care services among this age group. Although inclusion of fewer eligible participants than anticipated complicated study enrollment, it supports the potential role of an online intervention that does not require individuals to live near each other or travel to a designated location and could connect people across a broader geographic area.

We also faced a few challenges during implementation of the study. Considering the limitations of the study phones, future interventions should use smartphones, which are increasingly popular and affordable, even in low- and middle-income countries [45]. Network coverage problems also limited use of the intervention among some participants. Despite these challenges, most subjects participated in most sessions.

Surprisingly, all participants who voiced an opinion preferred online support groups, either alone or in combination with an in-person group, but none of them preferred in-person groups alone. The global trend toward use of and comfort with social media among young people seems to have reached youths in periurban and rural southern Nigeria [46].

This study had a few limitations. The nonprobability sample prevents generalization of the results beyond the study sample. Social desirability bias may play a role in participants' responses to questions about the intervention. In addition, we adapted only 5 of 14 sessions from Positive Connections; therefore, we do not know if participation may change with a longer curriculum. Moreover, we could not determine if facilitators drove participation or group member participation drove facilitator engagement.

In conclusion, this feasibility study demonstrated that an online support group intervention was both feasible and acceptable among ALHIVs in southern Nigeria. Our results provide guidance on changes required to enhance participation. Based on these findings, we have adapted the intervention and expanded it to include the remaining Positive Connections topics. A subsequent randomized controlled trial will test the cost-effectiveness of this revised intervention to improve HIV treatment outcomes.

\section{Acknowledgments}

The authors would like to acknowledge the contributions of the United States Agency for International Development (USAID)-funded Strengthening Integrated Delivery of HIV/AIDS Services (SIDHAS) project for successful implementation of the intervention under study. Drs Hadiza Khamofu and Edward Oladele of FHI 360 ensured the coordination of intervention implementation with the SIDHAS project. Dr Oluwasanmi Adedokun from FHI 360 provided key information and direct support for selecting study sites and informing sampling through the use of the SIDHAS program data. Dr Ogha Okpokam from FHI 360 played a pivotal role in coordinating the logistics for study-related trainings and liaising between the health facilities, the study team, and the local partners. We would also like to acknowledge the CPRH study team and their efforts to successfully carry out data collection and enroll study participants in the intervention. We especially would like to acknowledge Ms Hannah Silverstein from the University of North Carolina for her creative efforts in illustrating the intervention. Finally, we would like to thank the facilitators and adolescents who participated, without whom this research would not have been possible.

This study was funded by the USAID through the US President's Emergency Plan for AIDS Relief, under task order contract number AID-OAA-TO-15-00003 and YouthPower Action, under IDIQ contract number AID-OAA-I-15-00009, YouthPower: Implementation. The contents of this publication are the sole responsibility of FHI 360 and do not necessarily reflect the views of the USAID or the United States Government.

\section{Conflicts of Interest}

None declared.

\section{References}

1. Idele P, Gillespie A, Porth T, Suzuki C, Mahy M, Kasedde S, et al. Epidemiology of HIV and AIDS among adolescents: current status, inequities, and data gaps. J Acquir Immune Defic Syndr 2014 Jul 01;66 Suppl 2:S144-S153. [doi: 10.1097/QAI.0000000000000176] [Medline: 24918590] 
2. UNICEF Data: Monitoring the Situation of Children and Women: Turning the tide against AIDS will require more concentrated focus on adolescents and young people. 2018. Adolescent HIV prevention URL: https://data.unicef.org/topic/ hivaids/adolescents-young-people/ [accessed 2018-11-13] [WebCite Cache ID 73u0A7EKm]

3. UNAIDS. Global AIDS Update 2016. Geneva: Joint United Nations Programme on HIV/AIDS; 2016. URL: http://www. unaids.org/sites/default/files/media asset/global-AIDS-update-2016 en.pdf[WebCite Cache ID 73u0au4jX]

4. Ahonkhai AA, Banigbe B, Adeola J, Adegoke AB, Regan S, Bassett IV, et al. Age Matters: Increased Risk of Inconsistent HIV Care and Viremia Among Adolescents and Young Adults on Antiretroviral Therapy in Nigeria. J Adolesc Health 2016 Dec;59(3):298-304 [FREE Full text] [doi: 10.1016/j.jadohealth.2016.05.002] [Medline: 27329680]

5. Chandler C, Ngoksin A. Medbox. Bangkok: UNICEF; 2013. Lost in transitions: Current issues faced by adolescents living with HIV in Asia Pacific URL: https://www.medbox.org/countries/

lost-in-transitions-current-issues-faced-by-adolescents-living-with-hiv-in-asia-pacific/ preview?q=Papua+New+guinea[WebCite Cache ID 73u0lVV3k]

6. Denison JA, Banda H, Dennis AC, Packer C, Nyambe N, Stalter RM, et al. "The sky is the limit": adhering to antiretroviral therapy and HIV self-management from the perspectives of adolescents living with HIV and their adult caregivers. J Int AIDS Soc 2015;18:19358 [FREE Full text] [Medline: 25591915]

7. Lamb MR, Fayorsey R, Nuwagaba-Biribonwoha H, Viola V, Mutabazi V, Alwar T, et al. High attrition before and after ART initiation among youth (15-24 years of age) enrolled in HIV care. AIDS 2014 Feb 20;28(4):559-568 [FREE Full text] [doi: 10.1097/QAD.0000000000000054] [Medline: 24076661]

8. Mavhu W, Berwick J, Chirawu P, Makamba M, Copas A, Dirawo J, et al. Enhancing psychosocial support for HIV positive adolescents in Harare, Zimbabwe. PLoS One 2013;8(7):e70254 [FREE Full text] [doi: 10.1371/journal.pone.0070254] [Medline: 23894625]

9. NA. The Public Health Response. In: Cherry AL, Baltag V, Dillon ME, editors. International Handbook On Adolescent Health And Development: The Public Health Response. Geneva: Springer; 2017.

10. McNeely C, Blanchard J. The Teen Years Explained: A Guide to Healthy Adolescent Development. Baltimore, MD: Johns Hopkins Bloomberg School of Public Health; 2009. URL: https://www.jhsph.edu/research/centers-and-institutes/ center-for-adolescent-health/ includes/ pre-redesign/Interactive\%20Guide.pdf [accessed 2018-09-27] [WebCite Cache ID 72kFv9rq0]

11. Albert D, Chein J, Steinberg L. Peer Influences on Adolescent Decision Making. Curr Dir Psychol Sci 2013 Apr;22(2):114-120 [FREE Full text] [doi: 10.1177/0963721412471347] [Medline: 25544805]

12. FHI 360. Challenges and potential strategies for supporting adolescents living with HIV in Ndola, Zambia: Results from a study dissemination meeting Durham, NC. Durham, NC: Family Health International (FHI 360); 2014. URL: https://www. fhi360.org/sites/default/files/media/documents/Challenges\%20and\%20strategies\%20ALHIV\%20Zambia\%20Dissem brief. pdf[WebCite Cache ID 73u0qGE1T]

13. Nöstlinger C, Bakeera-Kitaka S, Buyze J, Loos J, Buvé A. Factors influencing social self-disclosure among adolescents living with HIV in Eastern Africa. AIDS Care 2015;27 Suppl 1:36-46 [FREE Full text] [doi: 10.1080/09540121.2015.1051501] [Medline: 26616124]

14. Murray KR, Dulli LS, Ridgeway K, Dal Santo L, Darrow de Mora D, Olsen P, et al. Improving retention in HIV care among adolescents and adults in low- and middle-income countries: A systematic review of the literature. PLoS One 2017;12(9):e0184879 [FREE Full text] [doi: 10.1371/journal.pone.0184879] [Medline: 28961253]

15. Ridgeway K, Dulli LS, Murray KR, Silverstein H, Dal SL, Olsen P, et al. Interventions to improve antiretroviral therapy adherence among adolescents in low- and middle-income countries: A systematic review of the literature. PLoS One 2018;13(1):e0189770 [FREE Full text] [doi: 10.1371/journal.pone.0189770] [Medline: 29293523]

16. Bhana A, Mellins CA, Petersen I, Alicea S, Myeza N, Holst H, et al. The VUKA family program: piloting a family-based psychosocial intervention to promote health and mental health among HIV infected early adolescents in South Africa. AIDS Care 2014 Jan;26(1):1-11 [FREE Full text] [doi: 10.1080/09540121.2013.806770] [Medline: 23767772]

17. Hickey MD, Salmen CR, Omollo D, Mattah B, Fiorella KJ, Geng EH, et al. Implementation and Operational Research: Pulling the Network Together: Quasiexperimental Trial of a Patient-Defined Support Network Intervention for Promoting Engagement in HIV Care and Medication Adherence on Mfangano Island, Kenya. J Acquir Immune Defic Syndr 2015 Aug 01;69(4):e127-e134 [FREE Full text] [doi: 10.1097/QAI.0000000000000664] [Medline: 25984711]

18. Holstad MM, Essien JE, Ekong E, Higgins M, Teplinskiy I, Adewuyi MF. Motivational groups support adherence to antiretroviral therapy and use of risk reduction behaviors in HIV positive Nigerian women: a pilot study. Afr J Reprod Health 2012 Sep;16(3):14-27 [FREE Full text] [Medline: 23437496]

19. Kaihin R, Kasatpibal N, Chitreechuer J, Grimes RM. Effect of an Empowerment Intervention on Antiretroviral Drug Adherence in Thai Youth. Behav Med 2015;41(4):186-194 [FREE Full text] [doi: 10.1080/08964289.2014.911717] [Medline: 24758271]

20. Luque-Fernandez MA, Van Cutsem G, Goemaere E, Hilderbrand K, Schomaker M, Mantangana N, et al. Effectiveness of patient adherence groups as a model of care for stable patients on antiretroviral therapy in Khayelitsha, Cape Town, South Africa. PLoS One 2013;8(2):e56088 [FREE Full text] [doi: 10.1371/journal.pone.0056088] [Medline: 23418518] 
21. Vu L, Burnett-Zieman B, Banura C, Okal J, Elang M, Ampwera R, et al. Increasing Uptake of HIV, Sexually Transmitted Infection, and Family Planning Services, and Reducing HIV-Related Risk Behaviors Among Youth Living With HIV in Uganda. J Adolesc Health 2017 Feb;60(2S2):S22-S28. [doi: 10.1016/j.jadohealth.2016.09.007] [Medline: 28109336]

22. Lester RT, Ritvo P, Mills EJ, Kariri A, Karanja S, Chung MH, et al. Effects of a mobile phone short message service on antiretroviral treatment adherence in Kenya (WelTel Kenya1): a randomised trial. Lancet 2010 Nov 27;376(9755):1838-1845. [doi: 10.1016/S0140-6736(10)61997-6] [Medline: 21071074]

23. Orrell C, Cohen K, Mauff K, Bangsberg DR, Maartens G, Wood R. A Randomized Controlled Trial of Real-Time Electronic Adherence Monitoring With Text Message Dosing Reminders in People Starting First-Line Antiretroviral Therapy. J Acquir Immune Defic Syndr 2015 Dec 15;70(5):495-502. [doi: 10.1097/QAI.0000000000000770] [Medline: 26218411]

24. Pop-Eleches C, Thirumurthy H, Habyarimana JP, Zivin JG, Goldstein MP, de Walque D, et al. Mobile phone technologies improve adherence to antiretroviral treatment in a resource-limited setting: a randomized controlled trial of text message reminders. AIDS 2011 Mar 27;25(6):825-834 [FREE Full text] [doi: 10.1097/QAD.0b013e32834380c1] [Medline: 21252632]

25. Rodrigues R, Shet A, Antony J, Sidney K, Arumugam K, Krishnamurthy S, et al. Supporting adherence to antiretroviral therapy with mobile phone reminders: results from a cohort in South India. PLoS One 2012;7(8):e40723 [FREE Full text] [doi: 10.1371/journal.pone.0040723] [Medline: 22952574]

26. Sabin LL, Bachman DeSilva M, Gill CJ, Zhong L, Vian T, Xie W, et al. Improving Adherence to Antiretroviral Therapy With Triggered Real-time Text Message Reminders: The China Adherence Through Technology Study. J Acquir Immune Defic Syndr 2015 Aug 15;69(5):551-559 [FREE Full text] [doi: 10.1097/QAI.0000000000000651] [Medline: 25886927]

27. Uzma Q, Emmanuel F, Ather U, Zaman S. Efficacy of Interventions for Improving Antiretroviral Therapy Adherence in HIV/AIDS Cases at PIMS, Islamabad. J Int Assoc Physicians AIDS Care (Chic) 2011;10(6):373-383. [doi: 10.1177/1545109710383175] [Medline: 21317163]

28. Gaysynsky A, Romansky-Poulin K, Arpadi S. "My YAP Family": Analysis of a Facebook Group for Young Adults Living with HIV. AIDS Behav 2015 Jun;19(6):947-962. [doi: 10.1007/s10461-014-0887-8] [Medline: 25186783]

29. Henwood R, Patten G, Barnett W, Hwang B, Metcalf C, Hacking D, et al. Acceptability and use of a virtual support group for HIV-positive youth in Khayelitsha, Cape Town using the MXit social networking platform. AIDS Care 2016 Dec;28(7):898-903. [doi: 10.1080/09540121.2016.1173638] [Medline: 27098208]

30. Cell Phones in Africa: Communication Lifeline. 2015. Pew Research Center URL: http://www.pewglobal.org/2015/04/15/ cell-phones-in-africa-communication-lifeline/ [accessed 2018-09-20] [WebCite Cache ID 72ZoT7cHl]

31. Akinfaderin-Agarau F, Chirtau M, Ekponimo S, Power S. Opportunities and limitations for using new media and mobile phones to expand access to sexual and reproductive health information and services for adolescent girls and young women in six Nigerian states. Afr J Reprod Health 2012 Jun;16(2):219-230. [Medline: 22916554]

32. Positive Connections: Leading Information and Support Groups for Adolescents Living with HIV internet. Durham, NC: FHI 360; 2013. URL: https://www.fhi360.org/sites/default/files/media/documents/positive-connections-2013.pdf]WebCite Cache ID 72ZpDUFEJ]

33. Grytics. France: ID Champagne-Ardenne \& Technopole de l'Aube en Champagne; BPI France; 2017. URL: https://grytics. com/ [accessed 2018-11-13] [WebCite Cache ID 73u1AXhQs]

34. IYWG. Positive Connections: Leading InformationSupport Groups for Adolescents Living with HIV. Durham, NC: FHI 360; 2013. URL: https://www.fhi360.org/sites/default/files/media/documents/positive-connections-2013.pdf]WebCite Cache ID 73u1SiDu7]

35. Facebook. What are the privacy settings for groups? 2016 URL: https://www.facebook.com/help/ 220336891328465?helpref=about content [accessed 2018-11-13] [WebCite Cache ID 73u2uG2DX]

36. Internet Data Calculator Internet. US: AT\&T; 2018. AT\&T URL: https://www.att.com/esupport/data-calculator/index.jsp [accessed 2018-09-20] [WebCite Cache ID 72ZpmUXxD]

37. Guest G, Macqueen K, Namey E. Applied Thematic Analysis. Thousand Oaks, CA: Sage Publications Inc; 2012.

38. Nvivo qualitative data analysis software. Version 11. Doncaster, Australia: QSR International Pty Ltd; 2015. QSR International URL: https://www.qsrinternational.com/nvivo/home [accessed 2018-11-13] [WebCite Cache ID 73u1XYzkj]

39. Mupambireyi Z, Bernays S, Bwakura-Dangarembizi M, Cowan FM. "I don't feel shy because I will be among others who are just like me...": The role of support groups for children perinatally infected with HIV in Zimbabwe. Child Youth Serv Rev 2014 Oct;45:106-113 [FREE Full text] [doi: 10.1016/j.childyouth.2014.03.026] [Medline: 25284920]

40. Herschman J, Kasenberg T, Levy D, Ruth N, Taberner C, Kaufman M, et al. Development of a smartphone app for adolescents with lupus: a collaborative meeting-based methodology inclusive of a wide range of stakeholders. Rev Panam Salud Publica 2014 Jun;35(5-6):471-476 [FREE Full text] [Medline: 25211579]

41. Nigeria Malaria Indicator Survey 2015. Abuja, Nigeria, and Rockville, Maryland, USA: National Malaria Elimination Programme, National Population Commission, National Bureau of Statistics, ICF International; 2016. URL: https:/ /dhsprogram.com/pubs/pdf/MIS20/MIS20.pdf [accessed 2018-11-13] [WebCite Cache ID 73u1cL9ko]

42. Kharsany ABM, Karim QA. HIV Infection and AIDS in Sub-Saharan Africa: Current Status, Challenges and Opportunities. Open AIDS J 2016;10:34-48 [FREE Full text] [doi: 10.2174/1874613601610010034] [Medline: 27347270]

43. Awofala AA, Ogundele OE. HIV epidemiology in Nigeria. Saudi J Biol Sci 2018 May;25(4):697-703 [FREE Full text] [doi: 10.1016/j.sjbs.2016.03.006] [Medline: 29740232] 
44. Akwa ISMOH, Akwa ISACOA, Federal MOH, National AFTCOA, Family HI. The Akwa Ibom State AIDS Indicator Survey Report-. Abuja, Nigeria: Akwa Ibom State Ministry of Health; 2018.

45. Silver L, Johnson C. Pew Research Center. 2018. Internet Connectivity Seen as Having Positive Impact on Life in Sub-Saharan Africa URL: http://www.pewglobal.org/2018/10/09/

majorities-in-sub-saharan-africa-own-mobile-phones-but-smartphone-adoption-is-modest/ [accessed 2018-11-07] [WebCite Cache ID 73kvwmCmG]

46. Poushter J, Stewart R, Chwe H. Pew Research Center. 2018. Social Media Use Continues To Rise in Developing Countries, but Plateaus Across Developed Ones URL: http://www.pewglobal.org/2018/06/19/

social-media-use-continues-to-rise-in-developing-countries-but-plateaus-across-developed-ones/ [accessed 2018-11-07] [WebCite Cache ID 73kw0X6FB]

\author{
Abbreviations \\ ALHIV: Adolescents living with HIV \\ ART: antiretroviral therapy \\ CD4: cluster of differentiation 4 \\ IDI: In-depth interview
}

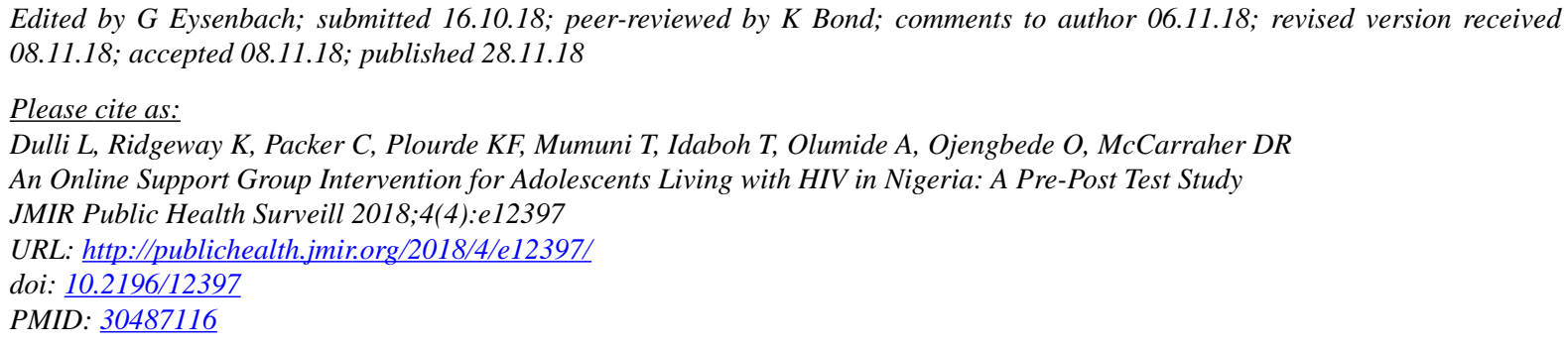

(CLisa Dulli, Kathleen Ridgeway, Catherine Packer, Kate F Plourde, Tolulope Mumuni, Tosin Idaboh, Adesola Olumide, Oladosu Ojengbede, Donna R McCarraher. Originally published in JMIR Public Health and Surveillance (http://publichealth.jmir.org), 28.11.2018. This is an open-access article distributed under the terms of the Creative Commons Attribution License (https://creativecommons.org/licenses/by/4.0/), which permits unrestricted use, distribution, and reproduction in any medium, provided the original work, first published in JMIR Public Health and Surveillance, is properly cited. The complete bibliographic information, a link to the original publication on http://publichealth.jmir.org, as well as this copyright and license information must be included. 